\title{
Pengaruh Model Pembelajaran dan Motivasi Belajar Terhadap Hasil Belajar IPS
}

\author{
Fitriyanti Fathan, Sarson W. Dj Pomalato, Abd Kadir Husain \\ 1,2,3 Pascasarjana Universitas Negeri Gorontalo \\ Email: fitriyanti@gmail.co.id
}

\begin{abstract}
ABSTRAK
Penelitian ini bertujuan mengetahui: (1) Pengaruh hasil belajar IPS yang dibelajarkan dengan model pembelajaran Think Pair and Share dengan siswa yang dibelajarkan dengan model pembelajaran Number Head Together (2) Interaksi antara model pembelajaran dan motivasi belajar terhadap hasil belajar IPS. (3) Pengaruh antara hasil belajar IPS terhadap siswa yang memiliki motivasi tinggi yang dibelajarkan dengan menggunakan model pembelajaran Think Pair and Share dan dengan menggunakan model pembelajaran Number Head Together. (4) pengaruh antara hasil belajar IPS terhadap siswa yang memiliki motivasi rendah yang dibelajarkan dengan menggunakan model pembelajaran Think Pair and Share dan dengan menggunakan model pembelajaran Number Head Together. Metode yang digunakan dalam penelitian ini adalah: Eksperimen Faktorial ANAVA dua jalur dengan uji tuckey. Hasil penelitian ini: (1) Hasil belajar IPS siswa yang dibelajarkan dengan menggunakan model Think Pair and Share lebih tinggi dari hasil belajar IPS siswa yang dibelajarkan dengan model Number Head Together (2) Terdapat pengaruh interaksi antara model pembelajaran dan motivasi belajar terhadap hasil belajar IPS (3) Terdapat perbedaan hasil belajar IPS pada kelompok siswa yang memiliki motivasi tinggi, yaitu hasil belajar IPS siswa yang dibelajarkan dengan model Think Pair and Share lebih tinggi dari pada siswa yang dibelajarkan dengan model Number Head Together (4) Terdapat perbedaan hasil belajar IPS pada kelompok siswa yang memiliki motivasi rendah, yaitu hasil belajar IPS siswa yang dibelajarkan dengan model Think Pair and Share lebih rendah dari pada siswa yang dibelajarkan dengan model Number Head Together.
\end{abstract}

Kata kunci: Think Pair and Share; Number Head Together; Motivasi belajar; Hasil belajar

\section{ABSTRACK}

This study aims to determine: (1) The effect of social studies learning outcomes that are taught with Think Pair and Share learning models with students who are taught with learning models Number Head Together (2) The interaction between learning models and learning motivation on social learning outcomes. (3) The effect of social studies learning outcomes on highly motivated students who are taught by using Think Pair and Share learning models and by using the Number Head Together learning model. (4) the effect of social studies learning outcomes on students who have low motivation are learned by using Think Pair and Share learning models and by using the Number Head Together learning model. The method used in this study is: Factorial two-way ANAVA experiment with the tuckey test. The results of this study: (1) Social studies learning outcomes of students who are taught by using the Think Pair and Share models are higher than the results of social studies learning students who are taught with the Number Head Together model (2) There is an influence of interaction between learning models and learning motivation towards social studies learning outcomes (3) There are differences in social studies learning outcomes in groups of students who have high motivation, namely the learning outcomes of social studies students who are taught with Think Pair and Share models are higher than students who are taught with the Number Head Together model (4) There are differences in social studies learning outcomes in the group of students who have low motivation, namely the results of social studies students who are taught with the Think Pair and Share model is lower than students who are taught with the Number Head Together model.

Keyword: Think Pair and Share; Number Head Together; learning motivation; learning outcomes

$$
\text { Pedagogika.fip@ung.ac.id P-ISSN : 2086-4469 E-ISSN : 2716-0580 }
$$




\section{PEDAGOGIKA}

Volume 10 (Nomor 1) 2019

Hal. 34-43

(C) 2019 Fitriyanti Fathan, Sarson W. Dj Pomalato, Abd Kadir Husain Under The License CC-BY SA 4.0

\section{PENDAHULUAN}

Pada dasarnya pendidikan adalah membangun gagasan dan emosi secara terus-menerus. Perubahan kesadaran manusia dari tidak tahu menjadi tahu, dari tahu menjadi mengerti dan dari mengerti menjadi paham, urutan perubahan itu pun dikenal dengan sebutan proses. Proses tersebut berlangsung tanpa henti memberikan karakter distingtif pada pendidikan. Proses tersebut juga membuat pembelajaran dalam pendidikan menjadi semacam proses yang menyenangkan dan terus mengalami perubahan, sebagaimana pemikiran dan perasaan yang juga terus dibangun dan dikembangkan secara berkelanjutan. Pendidikan yang berkualitas terletak pada cara guru dalam membelajarkan siswa.

Pembelajaran yang baik adalah pembelajaran yang merangkul pengalaman belajar tanpa batas mengenai bagaimana gagasan dan emosi berinteraksi dengan suasana kelas dan bagaimana keduanya dapat berubah sesuai suasana yang turut berubah (Joyce, Weil dan Calhoun, 2009: 6-7). Pembelajaran mengusahakan agar isi mata pelajaran bermakna bagi kehidupan siswa dalam membentuk kepribadiannya. Hal ini dapat tercapai bila dalam mengajar itu diutamakan pemahaman, wawasan, inisiatif, dan kerjasama dengan mengembangkan kreativitas siswa. Secara umum ada beberapa hal yang menyebabkan hasil belajar siswa tidak berahasil, diantaranya bila pembelajaran dilakukakan secara abstrak saja atau dengan kata lain guru hanya menyuruh siswa menghafal kata, fakta-fakta, rumusrumus seperti yang banyak terjadi dalam metode mengajar hanya berdasarkan pada buku. Terlebih lagi, dalam beberapa sekolah, umumnya proses pembelajaran diatur oleh masing-masing guru. Interaksi guru dan siswa hanya terbatas pada model pembacaan atau hafalan, guru akan menanyakan apa saja yang telah dipelajari, meminta salah seorang siswa untuk menjawab pertanyaan tersebut, kemudian membenarkan atau memperbaiki respon peserta didik (Sirotnik, 1983 dalam Joyce, Weil dan Calhoun, 2009: 296). Pola-pola evaluasi yang demikian menjadikan kelas sebagai ruang kompetensi antarsatu siswa dengan siswa lainnya. Tentu saja menurut beberapa penggagas teori pembelajaran kooperatif berpandangan bahwa pola-pola pendidikan individualistik, digabungkan dengan hafalan yang dikuasai seorang guru, sebenarnya merupakan hal yang kontra produkrif baik dalam tataran individu maupun sosial. Guru perlu 


\section{PEDAGOGIKA}

\section{Volume 10 (Nomor 1) 2019}

Hal. 34-43

mempersiapkan model pembelajaran untuk membuat siswa termotivasi dalam belajar dan membuat suasana belajar yang lebih aktif. Motivasi siswa sesungguhnya berkaitan erat dengan keinginan siswa untuk terlibat dalam proses pembelajaran. Motivasi sangat diperlukan bagi terciptanya proses pembelajaran di kelas secara efektif. Motivasi memiliki peranan yang sangat penting dalam pembelajaran, baik dalam proses maupun dalam pencapaian hasil. Hal ini sejalan dengan apa yang disampaikan oleh (Sadriman, 2014) bahwa motivasi dapat dikatakan serangkaian usaha untuk menyediakan kondisi-kondisi tertentu, sehingga seorang mau dan ingin melakukan sesuatu, dan bila ia tidak suka, maka akan berusaha untuk meniadakan atau mengelakan perasaan tidak suka itu. Selain motivasi, dalam pembelajaran juga dibutuhkan model pembelajaran yang sesuai dengan materi yang diajarkan, agar siswa tidak merasa bosan ketika mengikuti pembelajaran.

Model pembelajaran merupakan cara yang dipergunakan guru dalam mengadakan hubungan dengan siswa pada saat berlangsungnya pembelajaran. Model pembelajaran sangat diharapkan dapat membangun interaksi antara guru dengan para siswa dan mempertajam lingkungan/ suasana saat proses pembelajaran, sehingga beberapa praktek dalam penerapan metode pembelajaran menjadi sasaran kajian formal, diteliti dan dimanipulasi/ dipoles sehingga menjadi model yang dapat digunakan dalam mengembangkan keterampilan-keterampilan profesional untuk tugas-tugas pembelajaran

Salah satu model pembelajaran yang dikembangkan oleh para pakar penelitian pendidikan dalam upaya meningkatkan keaktifan dan keterampilan siswa adalah model pembelajaran kooperatif yang dikenal dengan cooperative learning.

Berdasarkan hasil penelitian (Sumartini, 2006:11) pembelajaran kooperatif dapat menjadikan siswa lebih aktif, lebih demokrastis, dan dapat mengembangkan pengetahuannya yang sesuai dengan potensi yang dimiliki oleh masing-masing peserta didik sehingga peserta didik terlibat partisipasi aktif, kritis dan kreatif dalam mengikuti proses pembelajaran.

Suasana kelas direncanakan dan dibangun sedemikian rupa sehingga siswa mendapatkan kesempatan untuk berinteraksi satu sama lain. Maksud dari interaksi ini adalah, siswa membentuk komunitas yang memungkinkan mereka mencintai proses pembelajaran. Selain itu hasil belajar yang diharapkan dapat tercapai dengan baik. 
PEDAGOGIKA

Volume 10 (Nomor 1) 2019

Hal. 34-43

1. Hakekat Hasil Belajar Siswa IPS Materi Peninggalan Sejarah HinduBudha dan Islam di Indonesia

Hasil belajar memberikan gambaran untuk menyatakan tingkat keberhasilan yang dicapai seorang siswa setelah melalui aktivitas. Hasil belajar dapat dijadikan pendorong bagi siswa dalam meningkatkan ilmu pengetahuan, dan berperan sebagai umpan balik dalam meningkatkan mutu pendidikan.

Menurut Driscoll (Uno, 2011: 195), menyatakan bahwa ada dua hal yang perlu diperhatikan dalam hal belajar yaitu (1) belajar adalah suatu perubahan yang menetap dalam kinerja seseorang, dan (2) hasil belajar yang muncul dalam diri siswa merupakan akibat atau hasil dari interaksi siswa dengan lingkungan. Pernyataan ini dapat diartikan bahwa apabila siswa belajar maka hasil belajar dapat dilihat dari kemampuannya melakukan suatu kegiatan baru yang bersifat menetap dari pada yang dilakukan sebelumnya sebagai akibat atau hasil dari interaksi siswa dengan lingkungan.

Dari hasil belajar siswa pada materi peninggalan Sejarah Hindu-Budha dan Islam Di Indonesia diperoleh bahwa hasil belajar yang menggunakan motivasi belajar tinggi hasilnya lebih tinggi dibandingkan dengan hasil belajar siswa yang motivasi belajarnya rendah.

\section{Tujuan Pembelajaran IPS}

Ilmu Pengetahuan Sosial (IPS) merupakan mata pelajaran yang menanamkan pengetahuan dan nilai nilai mengenai proses perubahan dan perkembangan sosial masyarakat dari masa lampau hingga masa kini. Oleh karena itu fungsi pembelajaran Ilmu Pengetahuan Sosial (IPS) bagi siswa adalah untuk memberikan pemahaman serta informasi awal mengenai fenomena-fenomena sosial yang terjadi di lingkungan sekitarnya. Dengan pemahaman seperti ini, maka siswa akan memperoleh pengetahuan tentang gejala-gejala sosial serta mampu melakukan interpretasi.

(Martorella dalam Etin dan Raharjo 2009) mengatakan bahwa pembelajaran pendidikan IPS lebih menekankan pada aspek "pendidikan" dari pada "transfer konsep", karena dalam pembelajaran pendidikan IPS siswa diharapkan memperoleh pemahaman terhadap sejumlah konsep pengetahuan dan mengembangkan serta melatih sikap, mental, nilai, moral, dan keterampilannya berdasarkan konsep yang telah dimilikinya.

\section{Model Pembelajaran Kooperatif}

Salah satu model pembelajaran yang berkembang saat ini adalah pembelajaran kooperatif. Pembelajaran ini menggunakan kelompok-kelompok kecil sehingga siswa siswa saling bekerja sama untuk mencapai 


\section{PEDAGOGIKA}

\section{Volume 10 (Nomor 1) 2019}

Hal. 34-43

tujuan pembelajaran. Siswa dalam kelompok kooperatif belajar berdiskusi, saling membantu dan mengajak satu sama lain untuk mengatasi masalah belajar.

\section{Pembelajaran}

kooperatif

mengkondisikan siswa untuk aktif dan saling member dukungan dalam kerja kelompok untuk menuntaskan materi masalah dalam belajar. (Agus Suprijono, 2009) mengungkapkan bahwa pembelajaran kooperatif adalah konsep yang lebih luas meliputi semua jenis kelompok termasuk bentuk-bentuk yang lebih dipimpin oleh guru atau diarahkan oleh guru. Sedangkan isjoni (2009: 14) mengemukakan bahwa pembelajaran kooperatif merupakan salah satu bentuk pembelajaran yang berdasarkan faham konstruktivis. Selanjutnya Stahl dalam Isjoni (2009: 15) menyatakan pembelajaran kooperatif dapat meningkatkan belajar siswa lebih baik dan meningkatkan sikap tolong menolong dalam perilaku sosial.

\section{a. Model Pembelajaran Think Pair and}

\section{Share}

Pembelajaran kooperatif tipe TPS merupakan pembelajaran kelompok dimana siswa diberi kesempatan untuk berfikir mandiri dan saling membantu dengan teman yang lain. Pembelajaran Think Pair Share merupakan model pembelajaran kooperatif dengan pendekatan struktural. Pendekatan ini memberi penekanan pada penggunaan struktur tertentu yang dirancang untuk mempengaruhi pola interaksi siswa. Think Pair Share merupakan suatu cara yang efektif untuk membuat variasi suasana pola diskusi kelas. Pembelajaran TPS membimbing siswa untuk memiliki tanggung jawab individu dan tanggung jawab dalam kelompok atau pasangannya.

\section{b. Model Pembelajaran Number Head}

\section{Together}

Number head together adalah suatu model pembelajaran yang lebih mengedepankan kepada aktivitas siswa dalam mencari, mengolah, dan melaporkan informasi dari berbagai sumber yang akhirnya dipresentasikan di depan kelas. NHT kali pertama dikenalkan oleh Spencer Kagan, dkk. (dalam Faturrohman, 2015: 82). Model NHT adalah bagian dari model pembelajaran kooperatif struktural, yang menekankan pada struktur-struktur khusus yang dirancang untuk mempengaruhi pola interaksi siswa. Struktur kagan menghendaki agar para siswa bekerja saling bergantung pada kelompok-kelompok kecil secara kooperatif. Struktur tersebut dikembangkan sebagai bahan alternatif dari struktur kelas tradisional seperti mengacungkan tangan terlebih dahulu untuk kemudian ditunjuk oleh guru untuk menjawab pertanyaan yang telah dilontarkan. 
PEDAGOGIKA

Volume 10 (Nomor 1) 2019

Hal. 34-43

\section{Motivasi belajar}

Manusia sebagai salah satu makhluk individu mempunyai sifat mendasar yang selalu melekat pada dirinya yaitu memiliki kondisi internal yang dapat mempengaruhi perilaku baik buruk dalam menjalankan aktivitas kehidupan seharihari. Salah satu kondisi internal tersebut adalah motivasi. Motivasi itu sendiri berawal dari kata "motif" yang dapat diartikan sebagai "daya penggerak yang telah menjadi aktif'.

Dalam kamus besar Bahasa Indonesia disebutkan bahwa motivasi adalah dorongan yang timbul pada diri sesorang secara sadar untuk melakukan sesuatu karena ingin. mencapai tujuan yang dikehendakinya atau mendapat kepuasan dengan perbuatannya.

Berdasarkan uraian di atas, maka penulis ingin melakukan penelitian dengan menetapkkan judul "Pengaruh Model Pembelajaran Tipe Kooperatif dan Motivasi Belajar terhadap Hasil Belajar IPS Tentang Peninggalan Sejarah HinduBudha dan Islam di Indonesia Pada Siswa Kelas V SDN 64 Kota Timur Kota Gorontalo".

\section{METODE PENELITIAN}

Metode yang digunakan untuk melaksanakan penelitian ini adalah metode eksperimen treatment by level dengan desain 2 X 2 ANAVA dengan melibatkan beberapa variabel yang dikelompokkan sebagai berikut:

a. Variabel Terikat $(\mathrm{Y})=$ Hasil Belajar IPS

b. Variabel Bebas $(\mathrm{X})=$ Model Pembelajaran Think Pair and Share dan metode pembelajaran Number Head Together

c. Variabel Atribut = Motivasi Belajar

Tabel 1. Desain Penelitian

\begin{tabular}{ccc}
\hline $\begin{array}{c}\text { Motivasi } \\
\text { Belajar }\end{array}$ & $\begin{array}{c}\text { Model pembelajaran Think Pair } \\
\text { and Share (A1) }\end{array}$ & $\begin{array}{c}\text { Model pembelajaran Number } \\
\text { Head Together (A2) }\end{array}$ \\
\hline Motivasi Belajar Tinggi & A1B1 & A2B2 \\
(B1) & & A2B2 \\
Motivasi Belajar Rendah & A1B2 & \\
\hline
\end{tabular}

HASIL PENELITIAN DAN Pembelajaran tipe think pair and share dan

\section{PEMBAHASAN}

Pembahasan hasil penelitian didasarkan pada hasil perlakuan penelitian dengan menggunakan dua model pembelajaran yang berbeda yaitu model model pembelajaran tipe number head together terhadap hasil belajar siswa ditinjau dari motivasi belajar siswa (motivasi belajar tinggi dan motivasi belajar rendah). 
PEDAGOGIKA

Volume 10 (Nomor 1) 2019

Hal. 34-43

Hasil temuan atau analisis data penelitian sebagaimana yang telah dipaparkan sebelumnya akan dijadikan pijakan untuk melakukan kajian atau analisis lebih lanjut tentang mengapa model pembelajaran tipe think pair and share lebih baik dari model pembelajaran tipe number head together, khususnya dalam mata pelajaran IPS dan juga mengapa terjadi interaksi antara model pembelajaran dengan motivasi belajar siswa dalam mempengaruhi hasil belajar IPS

Juga perlu dibahas tentang mengapa hasil belajar untuk siswa yang memiliki motivasi belajar tinggi yang dibelajarkan dengan model pembelajaran tipe think pair and share teruji lebih baik dibandingkan dengan yang dibelajarkan dengan model pembelajaran tipe number head together. Demikian pula, mengapa hasil belajar ips untuk siswa yang memiliki Motivasi Belajar rendah yang dibelajar dengan model pembelajaran tipe think pair and share dibandingkan dengan yang dibelajarkan dengan model pembelajaran tipe number head together tidak menunjukkan perbedaan yang signifikan.

1. Terdapat pengaruh hasil belajar IPS antara siswa yang dibelajarkan dengan model pembelajaran tipe think pair and share dan siswa yang dibelajarkan dengan model pembelajaran tipe number head together;

Hasil pengujian hipotesis pertama menunjukkan bahwa terdapat perbedaan hasil belajar IPS siswa yang diajar dengan model pembelajaran tipe think pair and share dan yang diajar dengan model pembajaran tipe number head together.Temuan penelitian ini menjelaskan bahwa secara keseluruhan penerapan model pembelajaran tipe number head together terhadap hasil belajar IPS lebih tinggi dari diskusi. Keunggulan model pembelajaran think pair and share ini dapat dijelaskan berdasarkan fungsi dan tujuan pembelajaran dalam kegiatan proses belajar yang memberikan kesempatan kepada siswa untuk saling bekerja sama dalam kelompok kecil, saling berbagi ilmu satu sama lain sehingga membuat siswa menjadi aktif .

Kesimpulan dari hasil temuan di atas, bahwa pembelajaran melalui model pembelajaran tipe think pair and share sangat mendukung motivasi belajar dan meningkatkan hasil belajar. Hal tersebut terjadi karena model pembelajaran tipe think pair and share membantu mengembangkan pola pikir proporsional, dengan kata lain, kegiatan kreatif dan pola pikir siswa harus dikembangkan semaksimal mungkin sesuai dengan kemampuan setiap siswa. Pembelajaran dengan model pembelajaran 


\section{PEDAGOGIKA}

\section{Volume 10 (Nomor 1) 2019}

Hal. 34-43

tipe think pair and share yaitu pembelajaran yang membuat seluruh siswa di dalam kelas dapat aktif, dan saling berbagi ilmu sehingga tidak terjadi kelas yang pasif. dengan mengajak siswa untuk mendisukusikan sebuah materi dan menyampaikan jawaban secara berpasangan di depan kelas. Sehingga tidak ada siswa yang tidak memiliki peran ketika proses pembelajaran berlangsung.

Berbeda dengan model pembelajaran tipe number head together dimana model ini merupakan model pembelajaran yang lebih berpusat kelompok besar dengan cara berhitung dan menggunakan nomor kepala dalam setiap kelompok. Dengan karakteristik dari masing-masing model pembelajaran tersebut dan berdasarkan perhitungan serta analisis data penelitian menunjukkan adanya perbedaan hasil belajar IPS siswa yang diajar dengan metode pembelajaran think pair and share dan metode pembelajaran diskusi.

\section{Terdapat pengaruh interaksi antara} metode pembelajaran dan motivasi belajar terhadap hasil belajar IPS;

Pengaruh interaksi menunjukkan bahwa antara model pembelajaran dengan Motivasi Belajar mempunyai sinergi yang positif terhadap hasil belajar IPS. Model pembelajaran sangat menentukan dalam keberlangsungan proses pembelajaran dalam kelas. Kondisi dan aktifitas siswa dalam proses pembelajaran IPS dapat dipengaruhi oleh pemilihan model pembelajaran tersebut. Model pembelajaran tipe think pair and share merupakan model yang dirancang agar setiap siswa secara berpasangan dapat saling sharing/berbagi ilmu yang dimiliki dengan teman sebangkunya.

Seperti yang telah diungkapkan dalam Bab II, bahwa motivasi akan menyebabkan terjadinya suatu perubahan energi yang ada pada diri manusia. Siswa akan belajar sungguh - sungguh apabila memiliki dorongan intrinsik dan ekstrinsik dengan beberapa indikator atau unsur yang mendukung. Melalui model pembelajaran tipe think pair and share siswa langsung mendapatkan pengalaman untuk saling berbagi ilmu yang dimiliki dan menyampaikannya di depan kelas. tantangan ini akan memotivasi setiap siswa untuk mencari tau materi yang dipelajari sehingga dapat mempengaruhi hasil belajar siswa.

Dengan Motivasi Belajar setiap siswa dalam proses pembelajaran akan lebih efektif dan efisien dalam meningkatkan hasil belajar IPS, seperti yang diuraikan diatas dan dengan merujuk pada hasil analisis data maka dapat dikatakan terdapat interaksi antara model pembelajaran tipe think pair and share dengan motivasi belajar siswa terhadap hasil belajar IPS siswa. 
PEDAGOGIKA

Volume 10 (Nomor 1) 2019

Hal. 34-43

3. Terdapat perbedaan hasil belajar IPS pada kelompok siswa yang memiliki motivasi tinggi, yaitu hasil belajar IPS siswa yang dibelajarkan dengan model Think Pair and Share lebih tinggi dari pada siswa yang dibelajarkan dengan model Number Head Together.

Dari hasil analisis data, telah terbukti bahwa terdapat perbedaan hasil belajar IPS yang memiliki Motivasi belajar tinggi dengan mengikuti pembelajaran dengan model pembelajaran tipe think pair and share dan model pembelajaran tipe number head together. Model pembelajaran tipe think pair and share sangat tepat dibandingkan model pembelajaran tipe number head together untuk diterapkan pada siswa yang memiliki motivasi belajar tinggi. Siswa yang memiliki motivasi tinggi memiliki karakteristik diantaranya dapat memberikan penjelasan tentang hal-hal yang ditemui dan langkah-langkah yang diambil, aktif dalam mengekspresikan ide yang muncul, menemukan ide-ide dan menjelaskan hubungan dari model yang digunakan. Siswa dapat rnelakukan pengembangan materi secara individual maupun kelompok tanpa harus takut dan malu untuk melakukan kesalahan. Sedangkan dalam pembelajaran menggunakan model number head together, pembelajaran berkelompok dengan jumlah anggota kelompok yang banyak, sehingga untuk membagi kelompok sulit juga mengakibatkan kelas menjadiu kacau kemudian pada prosesnya guru lebih sering memanggil siswa dengan nomor kepala yang sama secara terus menerus sehingga siswa lain tidak memiliki kesempatan untuk mengumukakan pendapatnya.

\section{Terdapat perbedaan hasil belajar IPS} pada kelompok siswa yang memiliki motivasi rendah, yaitu hasil belajar IPS siswa yang dibelajarkan dengan model Think Pair and Share lebih rendah dari pada siswa yang dibelajarkan dengan model Number Head Together.

Temuan penelitian ini mengindikasikan bahwa model pembelajaran number head together berpengaruh positif pada hasil belajar IPS untuk siswa yang memiliki motivasi belajar rendah, walaupun perbedaannya tidak signifikan. Hal ini cenderung dapat dijelaskan secara fenomena sebagai berikut: (a) siswa yang motivasi rendah, relatif lebih suka belajar pasif, kelompok yang banyak. Model pembelajaran tipe number head together lebih banyak mengandalkan interaksi yang komunikatif, sehingga cara ini dipandang lebih dapat diterima oleh siswa yang motivasi belajar rendah. Mereka merasa dilibatkan secara bersama-sama dan tanpa tekanan. Berbeda 


\section{PEDAGOGIKA}

\section{Volume 10 (Nomor 1) 2019}

\section{Hal. 34-43}

dengan think pair and share, pembelajaran lebih mengandalkan pemikiran secara berpasangan, keaktifan dan sikap saling berbagi ilmu satu dengan yang lain.

\section{KESIMPULAN}

Berdasarkan hasil pengujian hipotesis dan pembahasan penelitian maka dapat ditarik kesimpulan sebagai berikut: Terdapat perbedaan hasil belajar IPS siswa yang dibelajarkan dengan model pembelajaran tipe think pair and share lebih tinggi dibandingkan dengan hasil belajar siswa yang di belajarkan dengan model pembelajaran tipe number head together. Terdapat interaksi antara model pembelajaran dan motivasi belajar terhadap hasil belajar IPS siswa. Pada kelompok siswa yang memiliki motivasi belajar tinggi, hasil belajar IPS siswa yang dibelajarkan dengan model pembelajaran tipe think pair and share lebih tinggi dibandingkan hasil belajar IPS siswa yang dibelajarkan dengan meodel pembelajaran tipe number head together. Pada kelompok siswa yang memiliki motivasi belajar rendah, hasil belajar IPS siswa yang dibelajarkan dengan model pembelajaran tipe think pair and share lebih rendah dibandingkan hasil belajar IPS siswa yang dibelajarkan dengan model pembelajaran number head together. Dengan hasil penelitian ini menunjukkan bahwa model pembelajaran tipe think pair and share memberikan kontribusi positif dalam pembelajaran IPS.

\section{REFERENSI}

Agus Suprijono. 2009. Cooperative

Learning. Yogyakarta: Pustaka Belajar

Etin dan Raharjo. 2009. Cooperatif Learning Analisis Model Pembelajaran IPS. Jakarta: Bumi Aksara

Fathurrohman, Pupuh. Sobry Sutikno. 2014. Strategi Belajar Mengajar. Bandung: RefikaAditama

Isjoni. 2014. Cooperative Learning. Bandung: Alfabeta

Joyce, Bruce, Marsha Weil dan Emily Calhoun. (2009) Models of Teaching (Model-model Pengajaran Edisi Kedelapan). Yogyakarta: Pustaka Belajar.

Sadirman. 2014. Interaksi dan Motivasi Belajar Mengajar. Jakarta: Raja Grafindo Persada

Sumartini (2006). Pengaruh Pembelajaran Kooperatif terhadap Hasil Belajar Siswa pada Mata Pelajaran IPS. Bandung: UPI

Uno, Hamzah.2011. Model Pembelajaran. Jakarta:BumiAksara 